\title{
Новини від Української Світової Інформаційної Мережі
}

Українська Світова Інформаційна Мережа (УСІМ) оголошує конкурсний набір у волонтерський інформаційний корпус.

Конкурс відкритий для досвідчених журналістів-практиків, для молодих журналістів, для студентів-журналістів, журналістів-початківців (старшокласників), громадських кореспондентів і активістів різних фахів, які мають потяг до інформаційно-репортерської діяльності, в Україні та діаспорі сущих.

\section{NEWS FROM UKRAINIAN WORLDWIDE INFORMATION NETWORK}

Ukrainian Worldwide Information Network announces competitive recruitment to the volunteer information corps.

The competition is open to experienced practicing journalists, young journalists, student journalists, novice journalists (high school pupils), public correspondents, and activists of various professions who are attracted to information and reporting activities in Ukraine and the diaspora.

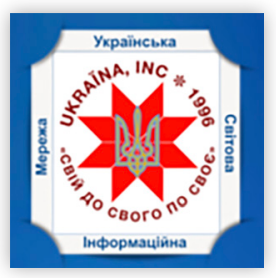

Для участі в конкурсі учасники мають зареєструватися, надіславши на електронну пошту уCIM ukrainainc@gmail.com таку інформацію:

1. Ім'я та прізвище учасника.

2. Рід занять, освіта, вік.

3. Місце роботи або навчання.

4. Контакти: поштову адресу, адресу електронної пошти і номер мобільного телефону.

Мета конкурсу - сформувати розгалужену кореспондентську мережу УСІМ, яка покривала б усю територію України та країни компактного проживання української діаспори.

Конкурс буде проводитися на мережевій сторінці групи «Українська Світова Інформаційна Мережа».

Основними ж критеріями оцінки публікацій будуть такі:

1. Фаховість вибору теми, її актуальність для суспільства в Україні й світового українства, для української справи.

2. Фаховість у доборі й викладі фактів, опису подій, осмислення явищ.

3. Вибір жанру, архітектоніка, культура викладу, стилістична досконалість тексту і, звичайно, грамотність. 
У конкурсі беруть участь лише оригінальні інформаційні й аналітичні матеріали, написані спеціально для УСІМ. Це означає, що кожен автор був очевидцем події, використав первинні джерела інформації й нічого ні в кого не запозичував.

У разі виявлення недоброчесності учасник/учасниця конкурсу буде дискваліфікований/дискваліфікована і його/ї̈ наступні матеріали не будуть розміщуватися на сторінці групи.

Кращі матеріали тижня й місяця будуть публікуватися на сайті Української Світової Інформаційної Мережі.

Підсумки конкурсу буде оголошено наприкінці року.

Для відзначення переможців конкурсу встановлено такі премії:

одна перша премія - $\$ 100$.

Дві других - по \$50.

Чотири третіх - по $\$ 25$.

Українська Світова Інформаційна Мережа 